\title{
The Role of Tea Tree Oil in Alleviating Palmitic Acid-Induced Lipid Accumulation in Bovine Hepatocytes
}

\author{
Tianyu Yang, Xiaoyu Ma, Maocheng Jiang, Zhiqiang Cheng, Osmond Datsomor, \\ Guoqi Zhao and Kang Zhan*
}

Institute of Animal Culture Collection and Application, College of Animal Science and Technology, Yangzhou University, Yangzhou, China

Tea tree oil (TTO) plays an important role in lipid metabolism, alleviating the inflammatory responses. Fatty liver is associated with lipid accumulation in hepatocytes, leading to inflammation. However, there is very limited information on the effects of TTO on lipid accumulation, and inflammation in bovine hepatocytes. This study aimed to evaluate whether TTO alleviates palmitic acid (PA)-induced lipid accumulation in bovine hepatocytes. Hepatocytes isolated from mid-lactating Holstein cows were pretreated with $100 \mu \mathrm{M}$ PA for $72 \mathrm{~h}$. Cells were either pretreated with PA alone (PA group) or with PA followed by $0.00625 \% \pi \mathrm{TO}$ treatment for $12 \mathrm{~h}$ (PT group). Expression of fatty acid oxidant genes increased $(P<0.05)$ while fatty acid synthesis genes decreased $(P<$ $0.05)$ in the PT group compared with the PA group. PA treatment resulted in increased $(P<0.05)$ expression of tumor necrosis factor- $\alpha(T N F-\alpha)$ and interleukin-6 (IL-6), but these increases were less in the PT group $(P<0.05)$. Compared to the PA group, expression of phosphorylated (p)-p65 and p-inhibitor $\kappa B \alpha\left(p-I_{\kappa} B \alpha\right)$ was suppressed $(P<0.05)$ by $T$ TO treatment. TTO treatment limited $(P<0.05)$ the increase in intracellular reactive oxygen species $(\mathrm{ROS})$ and prevented $(P<0.05)$ a reduction in mitochondrial membrane potential observed in response to PA treatment. Expression of endoplasmic reticulum (ER) stress genes was reduced $(P<0.05)$ in the PT group compared with the PA group. Our results suggest that $\Pi \mathrm{TO}$ treatment attenuates the effects of PA in hepatocytes, leading to fatty acid oxidation, decreased fatty acid synthesis, suppressed inflammatory response, and reduced ER stress. Taken together, the results of this study suggest that TTO treatment may be a promising therapeutic approach to imbalanced lipid homeostasis, inflammation and ER stress in dairy cows shortly before and after calving.

Keywords: tea tree oil, bovine hepatocytes, fatty acid metabolism, inflammation, endoplasmic reticulum stress

\section{INTRODUCTION}

The transition period in dairy cattle, which spans from 3 weeks before to 3 weeks after calving, is a profoundly challenging time due to increases in energy requirements associated with gravidity and lactogenesis lead that to cattle entering a state of negative energy balance $(1,2)$. Drackley et al. reported that energy demands increase $\sim 3$-fold in early-lactating cattle relative to non-lactating and pregnant cattle (3). However, cows exhibit a reduction in voluntary dry matter intake during the transition period. Therefore, cattle have to mobilize fat depots to release fatty acids as an energy source to compensate for reduced energy intake. 
Reynolds et al. demonstrated that excessive amounts of fatty acid are transported to the liver during the transition period (4). During lipolysis, palmitic acid (PA) participates in fatty acid release from fat depots (5). PA is a common dietary long-chain free fatty acid; it is most abundant in liver triglycerides (TGs) in both normal cows and those with steatosis. Rukkwamsuk et al. reported a significant increase in PA in dairy cows with fatty livers induced by high energy diets after parturition (5). Therefore, PA plays an important role in inducing fat deposits in the liver. When fatty acid uptake exceeds the rates of oxidation, they are stored as TGs (6). Bobe et al. reported that accumulation of high levels of fat in the liver can lead to metabolic disorders such as ketosis and fatty liver (7). Fatty liver is the most common form of chronic liver disease in high-yield dairy cows during the transition period (8-10). More than $40 \%$ of high-yield dairy cows suffer mild or moderate fatty liver and 5-10\% suffer from severe fatty liver (7). Fatty liver is associated with lipid accumulation in hepatocytes, leading to endoplasmic reticulum (ER) stress, inflammation, and oxidative stress $(11,12)$, which cause huge economic losses (7). Therefore, understanding the molecular mechanism of fatty liver and identification of effective therapeutic strategies is of the utmost importance.

Dairy cows with fatty liver have over-active nuclear factor $\kappa \mathrm{B}$ $(\mathrm{NF}-\kappa \mathrm{B})$ in the liver, leading to elevated cytokine secretion (13). The NF- $\mathrm{B}$ signal transduction pathway induces expression of genes related to pro-inflammatory cytokines via phosphorylation

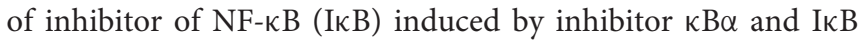
kinase in the cytosol (14). In addition, fatty liver in highyielding dairy cows is associated with significantly increased inflammation and related cytokines, including interleukin- $1 \beta$ (IL-1 $\beta$ ), tumor necrosis factor $\alpha$ (TNF- $\alpha$ ), and interleukin-6 (IL-6) (15).

Many essential oils extracted from plants contain secondary metabolites that exhibit anti-inflammatory activity (16). Tea tree oil (TTO), an essential oil derived from the Australian plant Melaleuca alternifolia, contains more than one hundred different compounds, mainly monoterpenes and their derivatives. The main components of TTO include terpinene-4-ol, $\gamma$-terpinene, $\alpha$-terpinene, 1,8-cineole, and $\alpha$-terpineol (17). Previous studies have focused on the antioxidant capacity and anti-inflammatory properties of TTO (16). In addition, fragrant herbal essential oils exert a significant effect on lipid metabolism by decreasing expression of SREBP1c and associated genes involved in fatty acid synthesis (18). However, to our knowledge, there is very limited information on the effects of TTO on lipid accumulation, inflammation, and ER stress in bovine hepatocytes, and we hypothesized that TTO can limit these effects.

Therefore, the objectives of this study were to evaluate the effects of TTO on lipid metabolism, inflammation, and ER stress in bovine hepatocytes in which lipid accumulation is experimentally induced by PA treatment.

\section{MATERIALS AND METHODS}

All trials plan and methods have authorized with the Animal Ethics Committee of Yangzhou University, China. The study conducted under the Care and Use of Laboratory Animals guidelines.

\section{Preparation of TTO}

Tea tree essential oil preliminary product were obtained from True Blue Organics (New Zealand). The TTO extract was carried out by Wuxi Chenfang Biotechnology Co., Ltd. (Wuxi, Jiangsu, China). The oil preliminary product was loaded into reaction still. Then, the nitrogen was added into the reaction still. In addition, reaction still continuously maintains the $0.2-1 \mathrm{~kg} / \mathrm{cm} 2$ pressure at $30-45^{\circ} \mathrm{C}, 45-70^{\circ} \mathrm{C}$, and $70-85^{\circ} \mathrm{C}$ for $1 \mathrm{~h}$, respectively. Oil pump was operated to keep the tea tree essential oils circulating in reaction still. Eventually, the cooling water was used to cool the tubes room temperature. The air compressor and nitrogen turn off, and stopping the essential oils circulating. The TTO extracts were analyzed by 9,790 gas chromatograph. The TTO major component are refer to previous paper (19). 0.1\% TTO: $10 \mu \mathrm{L}$ TTO was dissolved in $10 \mathrm{~mL}$ DMEM containing $0.1 \%$ dimethyl sulfoxide (DMSO). Subsequent experiments were performed by multiple dilution.

\section{Cell Culture}

Bovine hepatocytes of three mid-lactating Holstein cows were obtained from the Institute of Animal Culture Collection and Application, Yangzhou University. Hepatocytes were isolated from each cow separately, and all assays were done with cow considered as random. The caudate liver lobe of Holstein calves was obtained through surgical liver excision according to the methods of a previous study (20). The bovine hepatocytes were digested by collagenase IV (Invitrogen, Shanghai, China) perfusion as previously described by Liu et al. (21). Briefly, the caudate lobe of the bovine liver was obtained by surgical resection. Then the liver was soaked three times in $20 \mathrm{~mL}$ solution A [140 mM NaCl, $10 \mathrm{mM} \mathrm{N}$-2-hydroxyethylpiperazine$\mathrm{N}$-2-ethane sulfonic acid (HEPES), $6.7 \mathrm{mM} \mathrm{KCl,} 0.5 \mathrm{mM}$ ethylene diamine tetraacetic acid (EDTA), and $2.5 \mathrm{mM}$ glucose, $\mathrm{pH} 7.2$, $37^{\circ} \mathrm{C}$ ] and centrifuged at $120 \mathrm{rpm}$ for $10 \mathrm{~min}$, followed by immersion in solution $\mathrm{B}[140 \mathrm{mM} \mathrm{NaCl}, 30 \mathrm{mM}$ (HEPES), $6.7 \mathrm{mM} \mathrm{KCl}, 5 \mathrm{mM} \mathrm{CaCl}_{2}$, and $2.5 \mathrm{mM}$ glucose, $\left.\mathrm{pH} 7.2,37^{\circ} \mathrm{C}\right]$ and centrifugation at $120 \mathrm{rpm}$ for $10 \mathrm{~min}$. The liquid became cloudy, and the liver was perfused with collagenase IV solution $(0.1 \mathrm{~g}$ collagenase IV dissolved in $0.5 \mathrm{~L}$ of perfusion solution $\mathrm{B}$, $\mathrm{pH} 7.2$, at $37^{\circ} \mathrm{C}$ ) to digest the tissue. Digestion was terminated by addition of $50 \mathrm{~mL}$ fetal bovine serum (FBS; Gemini, Shanghai, China). The liver capsule, blood vessels, fat, and connective tissues were carefully removed using scissors and forceps. The remainder was cut into pieces and filtered successively through a $150 \mu \mathrm{m}$ mesh and a $75 \mu \mathrm{m}$ mesh. Hepatocytes were then washed twice with $\mathrm{PBS}$ at $4^{\circ} \mathrm{C}$, once with red blood cell lysis buffer, and suspended in Dulbecco's modified eagle medium (DMEM) medium supplemented with $10 \%$ FBS, $100 \mathrm{nM}$ insulin and 100 nM dexamethasone.

\section{PA/BSA Complex Solution Preparation}

The PA/BSA complex solution according to a previous study (22). A 100 mM PA (Sigma-Aldrich Co, Japan) stock solution was prepared in $0.1 \mathrm{M} \mathrm{NaOH}$ by heating at $70^{\circ} \mathrm{C}$ in a shaking water 
bath. In an adjacent water bath at $55^{\circ} \mathrm{C}$, a $10 \%$ (wt/vol) fatty acidfree BSA solution was prepared in DMEM medium. These two solutions were then mixed in varying proportions. For example, a $5 \mathrm{mM}$ PA/10\% BSA stock solution was prepared by adding $50 \mathrm{ml}$ of the $100 \mathrm{mM}$ PA solution dropwise to $950 \mathrm{ml} 10 \%$ BSA solution at $55^{\circ} \mathrm{C}$ in a shaking water bath, then vortexing for $10 \mathrm{~s}$ followed by a further $10 \mathrm{~min}$ incubation at $55^{\circ} \mathrm{C}$. The PA/BSA-complex was cooled to room temperature and passed through a sterile membrane filter $(0.45 \mathrm{~mm}$ pore size $)$ and stored at $-20^{\circ} \mathrm{C}$, where it was stable for 3-4 weeks. BSA stock solution ( $5 \mathrm{mM} \mathrm{PA} / 10 \%$ BSA) was heated for $15 \mathrm{~min}$ at $55^{\circ} \mathrm{C}$ and then cooled to room temperature before use.

\section{Screening of PA Concentration}

Hepatocytes were plated in 6-well plates at a density of $2 \times 10^{5} /$ well, and then cultured in a complete DMEM. After incubation for $12 \mathrm{~h}$, hepatocytes were maintained in DMEM containing $3 \%$ BSA and treated with $0,50,100$, or $200 \mu \mathrm{M}$ PA for 48, 72, or $96 \mathrm{~h}$, replacing the medium every $24 \mathrm{~h}$. After incubation, the levels of very low-density lipoprotein (VLDL) in hepatocytes were determined using ELISA kits (Shanghai Bluegene Biotech Co. Ltd, Shanghai, China) (21), the content of ATP in hepatocytes was determined using assay kit (Nanjing Jiangcheng Biotechnology Institut, Nanjing., China), and intracellular triglycerides were assayed using a triglyceride assay kit (Applygen Technologies Inc, Beijing, China), according to the manufacturer's protocol. All the samples were assayed in triplicate.

\section{Screening of TTO Concentration}

The cytotoxic effects of TTO on bovine hepatocytes were determined using the Cell Counting Kit-8 (CCK-8; Dojindo, Shanghai, China), according to the manufacturer's protocol. Bovine hepatocytes $\left(5 \times 10^{3}\right.$ cells/well $)$ were seeded into 96well plates. After $12 \mathrm{~h}$, bovine hepatocytes were incubated with $0.1 \%$ DMSO and either 0 (as a control), 0.001562, 0.003125, $0.006250,0.012500,0.025000,0.050000$, or $0.100000 \%$ TTO for $12 \mathrm{~h}$. Subsequently, $10 \mu \mathrm{L}$ CCK- 8 reagent was added to cells, followed by incubation at $37^{\circ} \mathrm{C}, 5 \% \mathrm{CO}_{2}$ for $2 \mathrm{~h}$. Absorbance at $450 \mathrm{~nm}$ was then measured in each well-using an auto-microplate reader (Thermo scientific, Shanghai, China). All the samples were assayed in sextuplicate.

After incubation for $12 \mathrm{~h}$, cells in 6-well-plates were twice rinsed gently with PBS, and then intracellular triglycerides were assayed using a triglyceride assay kit (Applygen Technologies Inc, Beijing, China). All the samples were assayed in triplicate.

\section{Experimental Design}

Bovine hepatocytes were seeded into 6 -well plates $\left(2.5 \times 10^{5}\right.$ cells/well). After $12 \mathrm{~h}$, the supernatant was removed and the cells were washed three times with PBS. The hepatocytes were divided into two groups that were pretreated with different solutions for 3 days, either 3\% BSA or $100 \mu \mathrm{M}$ PA in DMEM, replacing the medium every $24 \mathrm{~h}$. After 3 days of culture, discard the original culture medium. The BSA and PA groups were then each divided into two groups and treated with different solutions for $12 \mathrm{~h}$, either DMEM alone ("control" and "PA" groups for the BSA and
PA pretreatments, respectively) or DMEM containing 0.00625\% TTO ("TTO" and "PT" groups, respectively). All the samples were assayed in duplicate. Cells were exposed to optimized doses of $100 \mu \mathrm{M}$ PA and $0.00625 \%$ TTO according to the results of a dose-dependence assay (Figures 1, 2) in this study.

\section{Determination of TG Content}

The cell medium was removed using a micropipettor. Hepatocytes were harvested using a cell scraper and transferred into a centrifuge tube. Then, the cells were washed twice with ice-cold PBS. The cells were lysed using lysis buffer (Applygen Technologies Inc, Beijing, China) in room temperature for $20 \mathrm{~min}$. Subsequently, part of the lysate was reserved for protein quantification with BCA, and then remaining lysate was heated at $70^{\circ} \mathrm{C}$ for $10 \mathrm{~min}$. After heating, the lysate was centrifuged for $5 \mathrm{~min}$ at $2,000 \times \mathrm{g}$ at $4^{\circ} \mathrm{C}$, and the supernatant was used to determine the content of triglycerides with a commercial kit (Applygen Technologies Inc, Beijing, China), according to the manufacturer's protocol. Absorbance at $550 \mathrm{~nm}$ was then measured in each well-using an auto-microplate reader (Thermo scientific, Shanghai, China).

\section{Quantitative RT-PCR}

After incubation, total RNA was isolated from the cultured cells using a TRIzol kit (Tiangen, Beijing, China). Then, the OD-1,000 + Micro-Spectrophotometer was used to measure RNA purity and concentration, with RNA quality measured via electrophoresis (2\% agarose gels). In our study, the optical density (OD) 260/OD280 ratio of the total RNA was determined to be 1.9 , and the intensity of the $28 \mathrm{~S}$ ribosomal RNA band was approximately twice the intensity of the $18 \mathrm{~S}$ ribosomal RNA band in total RNA samples, indicating that total RNA was of high quality. Reverse transcription (RT) was performed using an RT Kit (Takara, Beijing, China). RT reaction mixtures contained $1 \mu \mathrm{g}$ total RNA and $1 \times$ PrimeScript RT Master Mix in a final volume of $20 \mu \mathrm{L}$, and reactions were performed for $15 \mathrm{~min}$ at $37^{\circ} \mathrm{C}$. Reverse transcriptase was inactivated by heating to $85^{\circ} \mathrm{C}$ for $5 \mathrm{~s}$. qRT-PCR assays were performed using SYBR $^{\circledR}$ Premix Ex TaqTM II Kit (Takara). The qRT-PCR reaction mixture contained $1 \times$ SYBR $^{\circledR}$ Premix Ex TaqTM II, $0.4 \mu \mathrm{M}$ each forward and reverse primers, and $100 \mathrm{ng}$ cDNA templates in a final volume of $20 \mu \mathrm{L}$, and reactions were performed as follows: initial denaturation at $95^{\circ} \mathrm{C}$ for $30 \mathrm{~s}$, followed by 40 cycles at $95^{\circ} \mathrm{C}$ for $5 \mathrm{~s}$ and $60^{\circ} \mathrm{C}$ for $30 \mathrm{~s}$. Before the qRT-PCR for samples, the amplification efficiencies of all primers were determined by using standard dilution series. The primers used are listed in Table 1. RefFinder (http://www.leonxie.com/referencegene. php), including Normfinder, geNorm, and the comparative $\triangle \mathrm{CT}$ method, was used to select the first-rank reference gene (ACTB, and GAPDH) by determining the candidate genes' ranking. The final ranking was calculated by assigning an appropriate weight value to each gene, and the geometric mean of their weight values for the overall final ranking was confirmed. A higher expression stability was indicated by a lower gene geomean of ranking value. Eventually, the most stable reference gene was screened for subsequent study. In addition, GAPDH, already known to be suitable for hepatocytes (28). Therefore, GAPDH was used 
A

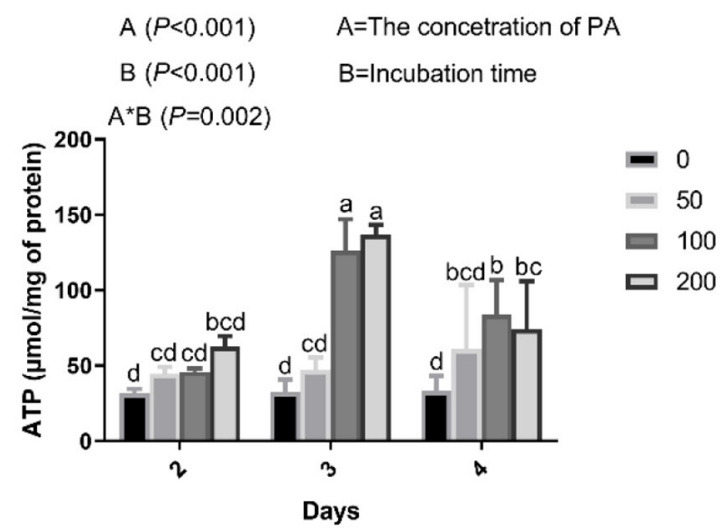

B

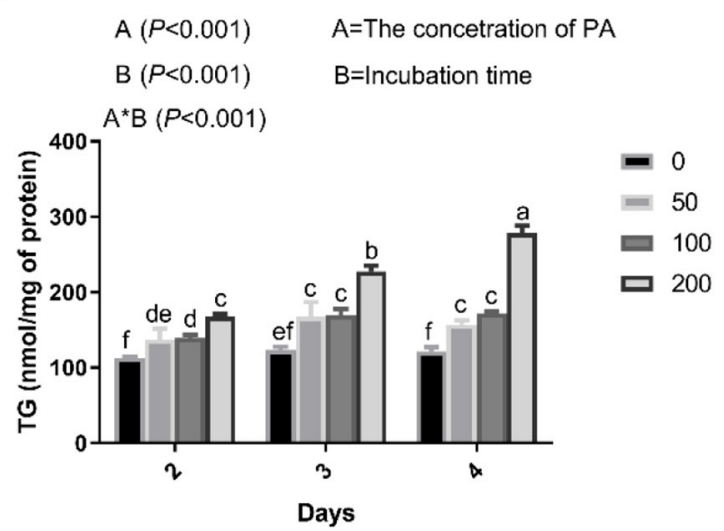

C

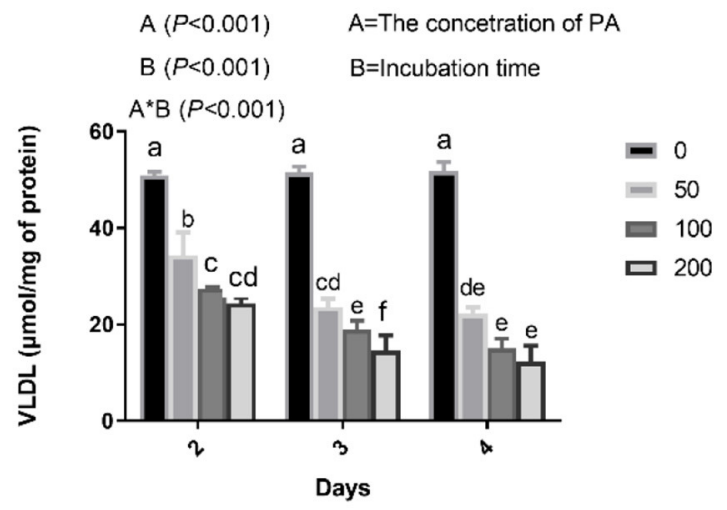

FIGURE 1 | Effects of palmitic acid (PA) on mitochondria and lipid metabolism in bovine hepatocytes. Bovine hepatocytes were treated with different concentrations of PA $(0,50,100$, and $200 \mu \mathrm{M})$ for 48, 72, or $96 \mathrm{~h}$. (A) Adenosine triphosphate (ATP) content in bovine hepatocytes. (B) Triglyceride (TG) content in bovine hepatocytes. (C) Very low-density lipoproteins (VLDL) content in bovine hepatocytes. Data are presented as mean \pm SEM $(n=3)$. Means at the different concentration of PA indicated by different letters (a-f) differ significantly. The letters in superscript indicate that the difference between groups was significant $(P<0.05)$.
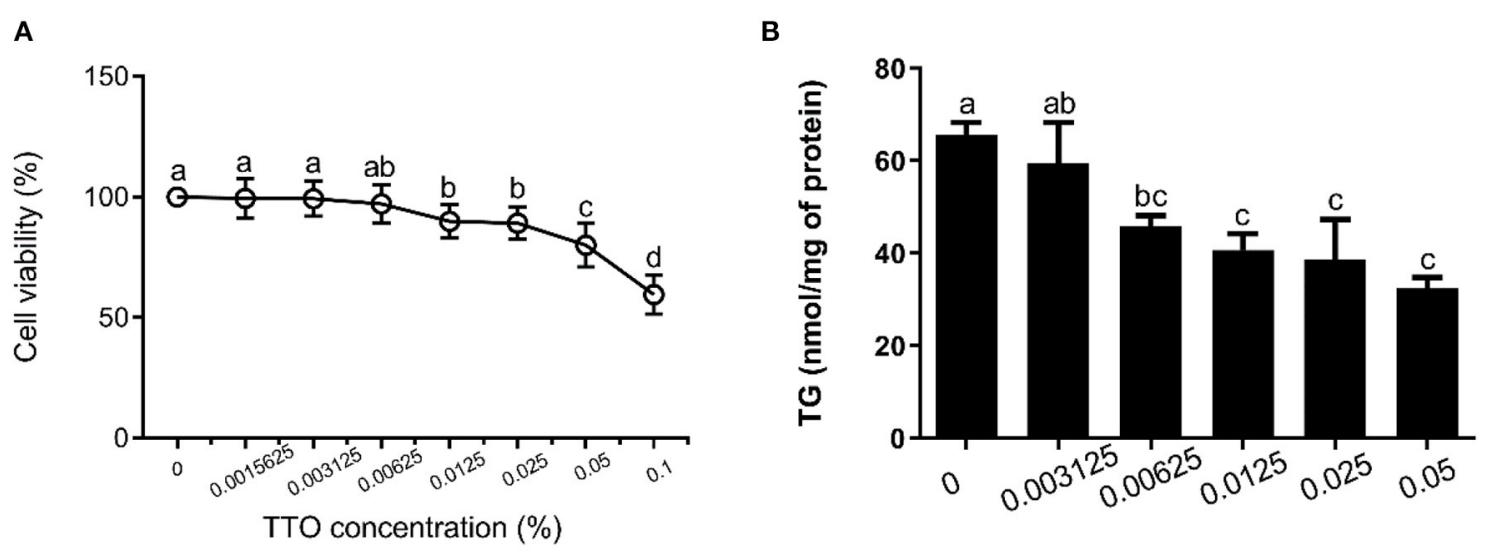

FIGURE 2 | Effect of tea tree oil (TTO) on cytotoxicity and triglyceride (TG) content in bovine hepatocytes. Cells were treated with various concentrations of $T$ TO for $12 \mathrm{~h}$. (A) Cytotoxic effects of TTO. (B) The effect of TTO on TG content. 
TABLE 1 | Primers for real-time PCR analyses.

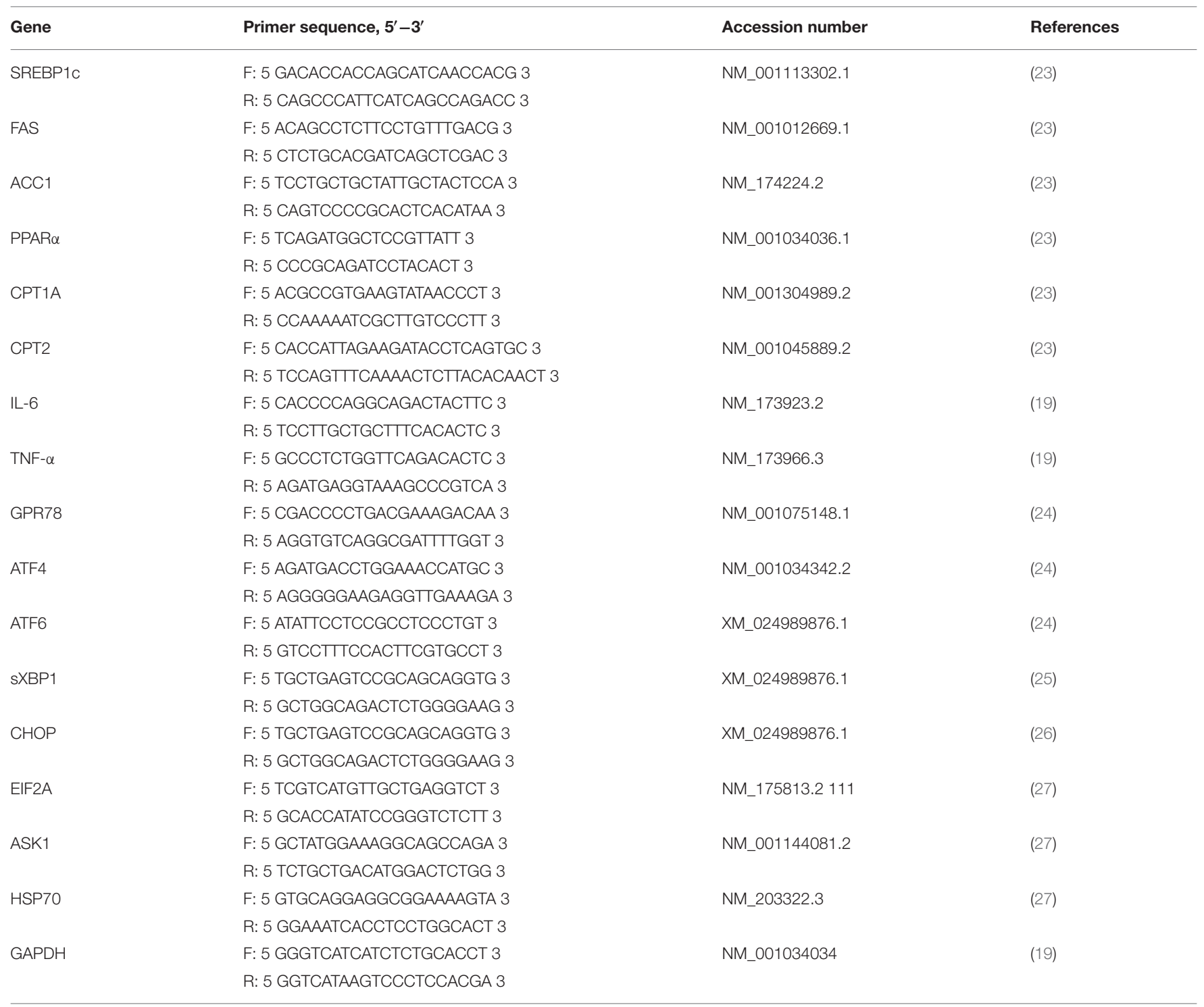

F, forward; R, reverse; NM, mRNA RefSeq; XM, predicted mRNA RefSeq; SREBP1c, sterol regulatory element binding protein-1c; FAS, fatty acid synthase; ACC1, CoA carboxylase 1; PPAR $\alpha$, peroxisome proliferator-activated receptor $\alpha$; CPT1A, carnitine palmitoyltransferase 1A; IL-6, interleukin-6; TNF- $\alpha$, tumor necrosis factor $\alpha$; GPR78, 78 kDa glucose-regulated protein; ATF4, AMP-dependent transcription factor 4; ATF6, activating transcription factor-6; sXBP1, spliced X-box binding protein 1; CHOP, C/EBP homologous protein; EIF2A, eukaryotic initiation factor 2A; ASK1, apoptosis signal-regulating kinase 1; HSP70, 70-kDa heat shock protein; GAPDH, Glyceraldehyde-3-phosphate dehydrogenase.

to normalize target gene abundance, followed by calculation of abundance using the $2^{-\Delta \Delta C T}$ method (29). All the samples were assayed in triplicate.

\section{Western Blotting}

The target protein abundance in the hepatocytes was quantified following a published protocol (30). After incubation, the 3 $\times 10^{6}$ cells in $10 \mathrm{~cm}$ dish were twice rinsed gently with PBS followed by lysis using RIPA Lysis (Thermo Scientific, Shanghai, China) containing a $1 \times$ protease inhibitor cocktail (Thermo Scientific) and $1 \times$ phosphatase inhibitor cocktail (Roche, Shanghai, China). Protein concentrations were determined using a BCA kit (Beyotime, Beijing, China). Equal amounts
(40 $\mu \mathrm{g}$ ) of protein lysates were fractionated by SDS-PAGE and transferred to nitrocellulose membranes (PALL, Shanghai, China). The membranes were blocked with $5 \%$ horse serum and then incubated with primary antibody plus $5 \%$ horse serum in Tris-buffered saline with Tween (TBS-T: $10 \mathrm{mM}$ Tris-HCl, $\mathrm{pH} 7.5,150 \mathrm{mM} \mathrm{NaCl}, 0.05 \%$ Tween 20) using gentle shaking overnight at $4{ }^{\circ} \mathrm{C}$. Antibodies to GAPDH, phosphorylated (p)p65, and FAS $(1: 1,000)$ were obtained from CST (Shanghai, China), to SREBP1c (1:1,000) from Novus Biologicals (USA), and $\mathrm{p}-\mathrm{I} \kappa \mathrm{B} \alpha(1: 1,000)$ from Affinity (USA). The horseradish peroxidase (HRP)-conjugated secondary antibody was goat antirabbit IgG (1:5,000; CST). The target bands were detected using the Super Signal West Femto Maximum Sensitivity Substrate or 
Pierce ECL Plus Western Blotting Substrate (Thermo Scientific). Densitometric analysis of the bands was performed using ImageJ software (Wayne Rasband). All the densitometric values were normalized to the GAPDH (28).

\section{ROS Generation}

$2^{\prime}, 7^{\prime}$-Dichlorodihydrofluorescein diacetate (DCFH-DA) can diffuse into cells, where it is hydrolyzed to DCFH by intracellular esterase. Intracellular ROS oxidizes non-fluorescent DCFH into fluorescent DCF. Intracellular ROS in bovine hepatocytes were measured by a Reactive Oxygen Species Assay Kit containing a DCFH-DA probe (Solarbio, China), according to the manufacturer's protocol (31). Cells $\left(4 \times 10^{5}\right.$ cells) were harvested and incubated with DCFH-DA at $25^{\circ} \mathrm{C}$ for $20 \mathrm{~min}$. Fluorescence intensity was analyzed by flow cytometry (FACS LSRFortessa, USA).

\section{Mitochondrial Membrane Potential $(\Delta \Psi \mathrm{m})$ Analysis}

The bovine hepatocytes mitochondrial membrane potential was detected by a mitochondrial membrane potential assay kit with JC-1 (Solarbio, China) following the manufacturer's protocol (31). At the end of the treatment period, cells $\left(4 \times 10^{5}\right.$ cells $)$ were collected in a polystyrene centrifuge tube and washed twice with wash buffer. Then, bovine hepatocytes were resuspended and incubated in a freshly prepared JC-1 working solution at $37^{\circ} \mathrm{C}$ for $20 \mathrm{~min}$. Cells were analyzed using flow cytometry (FACS LSRFortessa, USA).

\section{Statistics}

The screening of PA concentration was analyzed using twoway analysis of variance and the others results were evaluated by one-way analysis of variance (ANOVA), followed by determination of the least significant difference (LSD) for posthoc multiple comparisons of treatment means, using SPSS 19.0 software (SPSS Inc.; Chicago, IL, USA). $P$ values $<0.05$ were considered significant.

\section{RESULTS}

\section{Lipid Accumulation in Bovine Hepatocytes After PA Treatment}

We found that PA treatment gradually increased intracellular ATP, which was significantly higher in cells incubated with 100 and $200 \mu \mathrm{M}$ PA for 3 days (Figure 1A). Culture medium containing 50, 100, and $200 \mu \mathrm{M}$ PA significantly increased intracellular TG content after 2 days (Figure 1B) and VLDL content after 2 days (Figure 1C).

\section{Assessment of Cytotoxicity and Changes in TG Content in Response to TTO}

The effects of TTO on cytotoxicity and TG content in bovine hepatocytes are shown in Figure 2. TTO at concentration of $0.001562,0.003125$ and $0.006250 \%$ had no cytotoxic effects on bovine hepatocytes $(P>0.05)$ (Figure 2A), and $0.006250,0.012500,0.025000$, and $0.050000 \%$ TTO elicited a decrease $(P<0.05)$ in TG content (Figure 2B).
Considering these results, $0.006250 \%$ TTO was selected for subsequent experiments.

\section{Effect of TTO on TG Content Following PA Treatment of Bovine Hepatocytes}

The changes in TG concentration in bovine hepatocytes treated with PA are shown in Figure 3A. Compared with the control group, TG concentration significantly decreased $(P<0.05)$ in response to TTO incubation, while it increased in response to PA. TTO treatment elicited a reduction $(P<0.05)$ in TG content in bovine hepatocytes pretreated with PA.

\section{Effect of TTO on the Expression of Genes Related to Fatty Acid Metabolism, Inflammation, and ER Stress in Bovine Hepatocytes Treated With PA}

Compared with the control group, PA stimulation increased $(P<0.05)$ expression of synthesis-related genes, including $S R E B P 1 c, F A S$, and $A C C 1$, and fatty acid oxidation genes (PPAR- $\alpha, C P T 1 A$, and CPT2) (Figure 3B). TTO treatment resulted in downregulation of FAS gene expression $(P<0.05)$ and upregulation of PPAR- $\alpha$ and CPT1A gene expression $(P<0.05)$ in bovine hepatocytes compared with the control group. Moreover, PT treatment exhibited decreased $(P<0.05)$ expression of FAS and SREBP1c genes and increased $(P<0.05)$ expression of $P P A R-\alpha$ and CPT1A genes.

Expression of genes related to the inflammatory response is shown in Figure 4A. PA stimulation elicited an increase $(P$ $<0.05)$ in $I L-6$ and $T N F-\alpha$ gene expression compared with the control group. PT group triggered $(P<0.05)$ expression of IL-6 and TNF- $\alpha$ genes in hepatocytes compared to that in PA-treated cells.

Figure 5 shows that compared with the control group, PA stimulation specifically triggered $(P<0.05)$ gene expression of the $78 \mathrm{kDa}$ glucose-regulated protein (GPR78), AMP-dependent transcription factor 4 (ATF4), activating transcription factor6 (ATF6), spliced X-box binding protein 1 (sXBP1), C/EBP homologous protein $(C H O P)$, eukaryotic initiation factor $2 \mathrm{~A}$ (EIF2A), apoptosis signal-regulating kinase 1 (ASK1), and 70$\mathrm{kDa}$ heat shock protein (HSP70). In addition, compared with control group $(P>0.05)$, TTO had no effect on the expression of genes related to ER stress. PT treatment exhibited decreased $(P<0.05)$ gene expression of GPR78, ATF4, ATF6, sXBP1, CHOP, EIF2A, ASK1, and HSP70, compared with that in PAstimulated hepatocytes.

\section{TTO Regulated Expression of Proteins Related to Fatty Acid Metabolism in PA-Stimulated Bovine Hepatocytes}

We assessed protein expression of FAS and SREBP1c by using western blotting (Figures 3C,D). Expression of proteins related to fatty acid synthesis, including FAS and SREBP1c, was reduced $(P<0.05)$ in the TTO group compared with the control group, but increased in the PA group. PT group exhibited decreased 
A

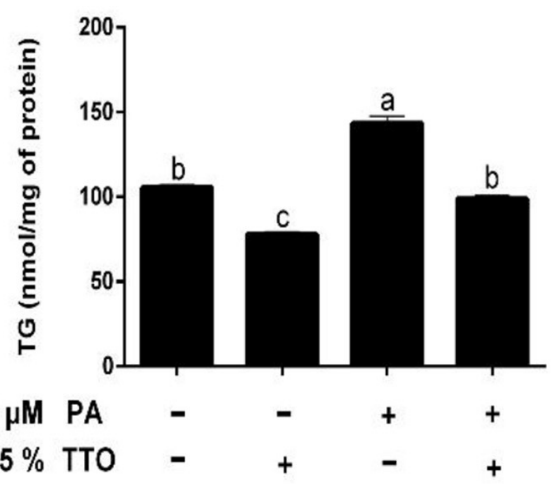

C

$\begin{array}{lllll}100 \mu \mathrm{M} \mathrm{PA} & - & - & + & + \\ 0.00625 \% \text { ТTО } & - & + & - & +\end{array}$

FAS

SREBP1C

GAPDH
B
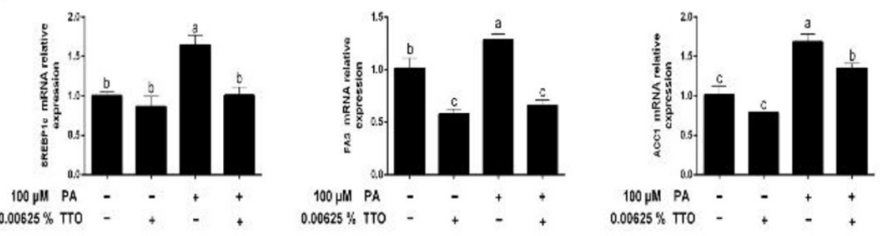
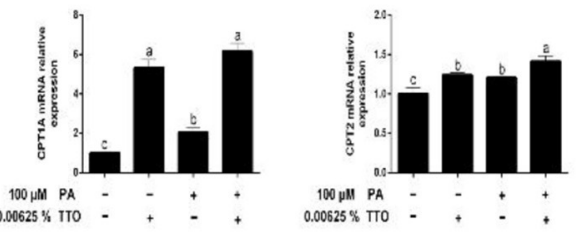

D
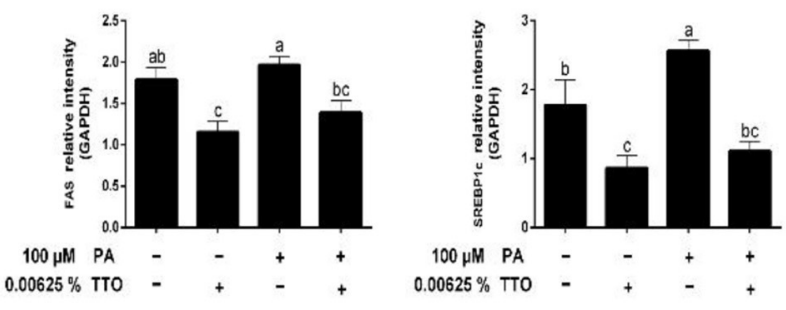

FIGURE 3 | Effect of TTO on genes and proteins related to fatty acid metabolism and TG content in PA-stimulated hepatocytes. (A) TG content. (B) Expression of genes related to fatty acid metabolism, normalized to GAPDH content. (C,D) Intensity of bands in immunoblots (C) and images of blots (D). Protein expression was normalized to GAPDH content. All results are expressed as mean \pm SEM. These data are representative of three independent experiments.

$(P<0.05)$ protein expression of FAS and SREBP1c compared with the PA-stimulated group.

\section{PA-Stimulated Expression of Proteins Associated With NF- $\kappa$ B Signaling Was Inhibited by TTO Treatment}

Levels of phosphorylated $\mathrm{I} \kappa \mathrm{B} \alpha$ and phosphorylated $\mathrm{p} 65$ are shown in Figures 4B,C. The levels of $\mathrm{p}-\mathrm{I} \kappa \mathrm{B} \alpha$ and $\mathrm{p}$-p65 in hepatocytes increased in response to PA stimulation, while TTO reduced $(P<0.05)$ protein expression of $\mathrm{p}-\mathrm{I} \kappa \mathrm{B} \alpha$ and $\mathrm{p}-\mathrm{p} 65$ compared to that in the control group. Compared with the PAtreatment group, PT treatment reduced $(P<0.05)$ expression of

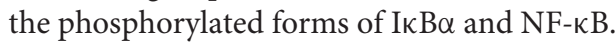

\section{TTO Stabilized Intracellular ROS Levels} and Mitochondrial Membrane Potential in Bovine Hepatocytes Stimulated With PA

To define antioxidant levels in an inflammatory environment and determine the functional status of mitochondria under oxidative stress, we measured intracellular ROS levels and mitochondrial membrane potentials in bovine hepatocytes (Figures 6A,B, 7A,B). Treatment with TTO reduced ( $P$ $<$ 0.05) intracellular ROS levels, while PA stimulation increased $(P<0.05)$ ROS levels compared with control group. In addition, PT group exhibited reduced $(P<0.05)$ intracellular ROS levels compared with the group treated by PA alone. 

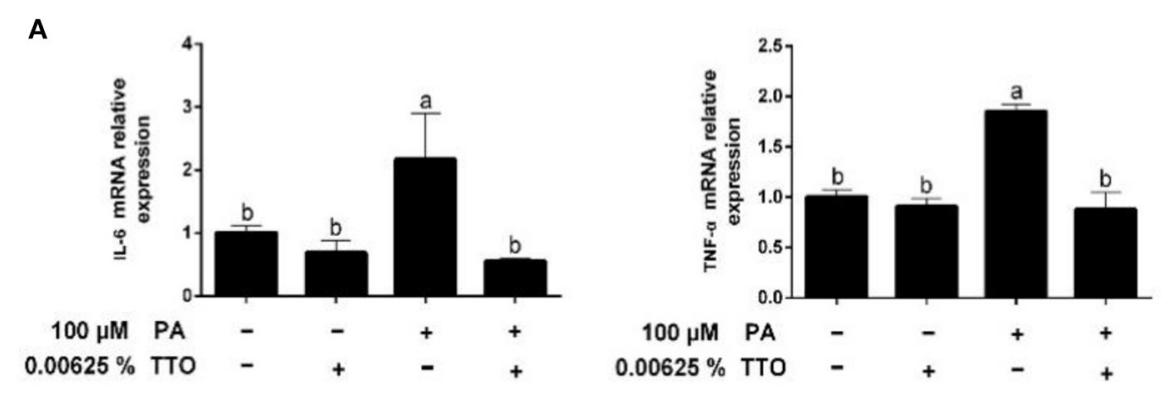

B

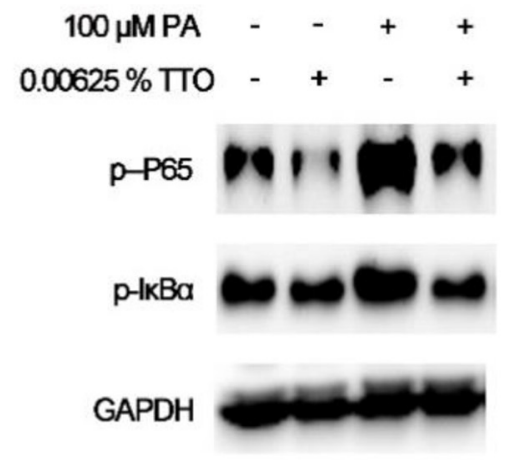

C

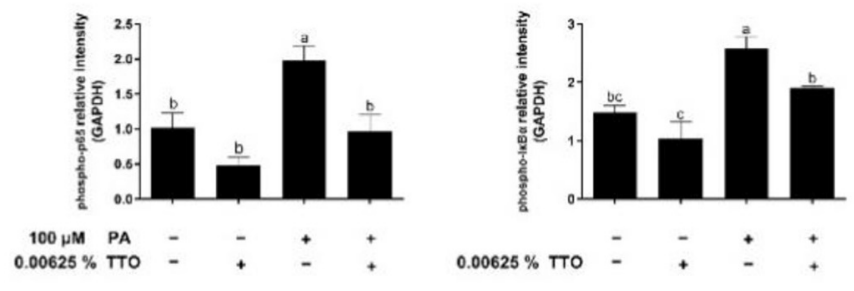

FIGURE 4 | Expression of genes and proteins related to inflammation in bovine hepatocytes treated with TTO (0.00625\%) and/or PA (100 $\mu$ M). (A) Expression of genes related to inflammatory response, normalized by GAPDH. (B,C) Immunoblots and corresponding intensities of the bands. Protein expression was normalized by the respective abundance of GAPDH. All results are expressed as the mean \pm SEM. The letters above the error bars indicate that the differences between groups was significant $(P<0.05)$. These data are representative of three independent experiments.

In healthy cells characterized by high mitochondrial membrane potential, JC-1 forms aggregates within mitochondria and emits red fluorescence. However, when cells have a low mitochondrial membrane potential, JC-1 remains monomeric in the cytoplasm and emits green fluorescence (32). Stimulation with PA lead to a collapse in mitochondrial membrane potential in bovine hepatocytes, but PT group prevented this change $(P<0.05)$.

\section{DISCUSSION}

During the transition period, dairy cattle experience tremendous physiological, metabolic, immunological, and nutritional changes $(33,34)$. To meet their energy demands, lipid mobilization of adipose tissue is an efficient physiological adaptation in dairy cattle (35). Increased lipid mobilization leads to an increase in blood fatty acids, which are absorbed by the liver, leading to TG accumulation in liver and an enhanced inflammatory response accompanied by ER stress $(34,36)$.

High levels of circulating saturated fatty acids are linked with fatty liver, obesity, and hyperlipidemia. The major circulating fatty acid is saturated PA (C16:0), which has been implicated in lipid accumulation (37). In addition, PA is a 16-carbon saturated fatty acid that is the first produced during lipogenesis. In this study, we chose to utilize PA treatment to induce lipid accumulation in bovine hepatocytes as a model of fatty liver. ATP production and TG concentration is higher, and VLDL is lower, in fatty liver compared with that in healthy cows $(21,37)$. Our study showed that after incubating bovine hepatocytes with $100 \mu \mathrm{M}$ PA for 3 days, there were significant increases in intracellular levels of TG and ATP, and a decrease in intracellular VLDL. Based on these results, bovine hepatocytes were stimulated with $100 \mu \mathrm{M}$ PA for 3 days in subsequent experiments.

Fragrant herbal essential oils can be beneficial for lipid metabolism (18). Our previous study demonstrated that TTO contains terpinen-4-ol, $\alpha$-terpinene, $\alpha$-terpineol, $\alpha$ pinene, p-cymene, and 1,8-cineole, $\gamma$-terpinene, terpinolene, and pinocarveol (19). The phytochemical content of p-cymene, which is harmful to humans and animals, is $<0.05 \%$. Notably, the content of terpinen-4-ol, which can inhibit secretion of cytokines such as IL- $1 \beta$, TNF- $\alpha$, and IL- 10 , is $\sim 60.23 \%$ (38). In addition, previous studies showed that TTO can play an important role as an anti-inflammatory agent (16). The present results showed 

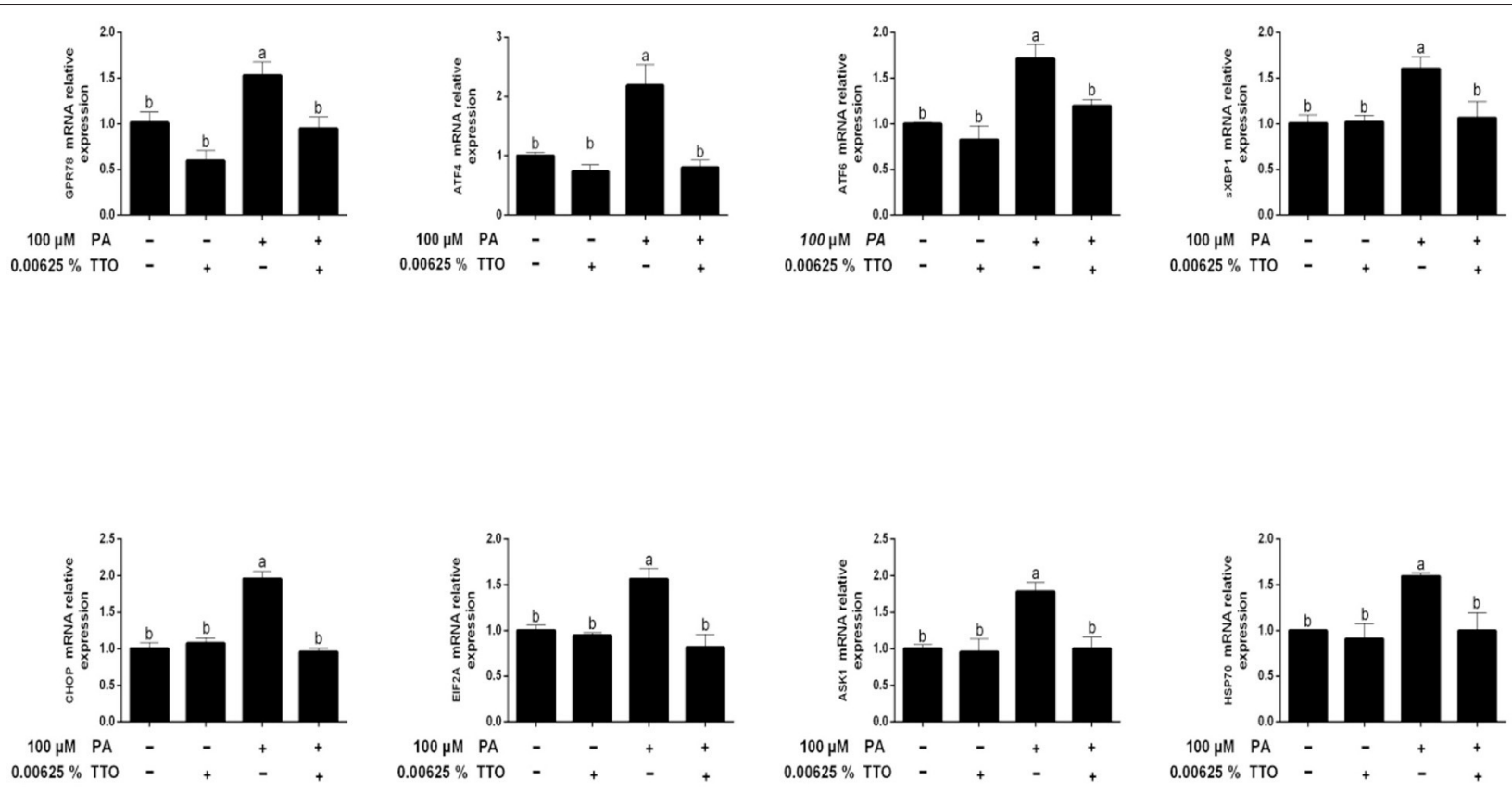

FIGURE 5 | Expression of genes related to endoplasmic reticulum stress in bovine hepatocytes treated with TTO (0.00625\%) and/or PA (100 $\mu$ M). Expression of genes related to endoplasmic reticulum stress, normalized by GAPDH. All results are expressed as the mean \pm SEM. The letters above the error bars indicate that the difference between groups was significant $(P<0.05)$. These data are representative of three independent experiments.

A

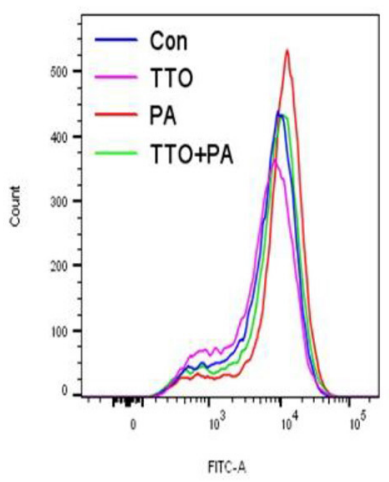

B

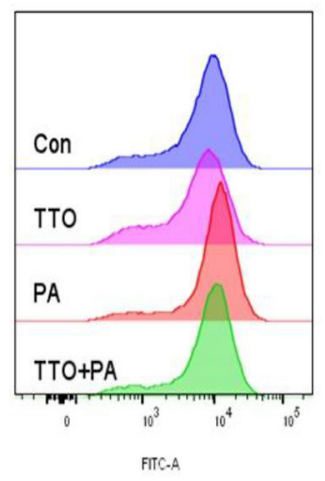

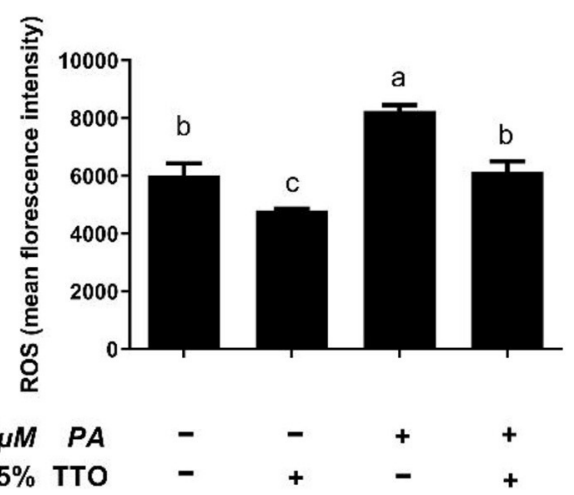

FIGURE 6 | The effect of TTO on ROS production. (A) ROS levels in bovine hepatocytes treated with TTO (0.00625\%) and/or PA (100 $\mu$ M). Cellular ROS generation following different treatments was measured by staining with DCFH-DA. The fluorescence was detected using flow cytometry. (B) Cellular ROS level. All results are expressed as the mean \pm SEM. The letters above the error bars indicate that the difference between groups was significant $(P<0.05)$. These data are representative of three independent experiments.

that $<0.00625 \%$ TTO did not impair cell viability of bovine hepatocytes and more than $0.00625 \%$ TTO elicited a remarkable decrease in TG content. Notably, $0.00625 \%$ TTO can also reduce TG concentration in PA-stimulated bovine hepatocytes. Therefore, TTO is a potential treatment option for reducing lipid accumulation induced by PA in bovine hepatocytes.

Fatty liver can occur when hepatic lipid synthesis exceeds the rate of oxidation and secretion of lipids by the liver (7). Compared with absorption of fatty acids, their synthesis in the liver has less effect on production of milk fat in the mammary glands of bovines. Fatty liver may be caused by a disturbance of the energy balance of dairy herds. Therefore, the regulation of liver lipid homeostasis plays an important role in maintaining normal physiological function. Interestingly, addition of TTO to PA-stimulated hepatocytes reduced cellular TG content to the same level as in the control group. Du et al. reported that hepatic lipid synthesis and oxidation were triggered in dairy cows with mild fatty liver (37). SREBPs are transcription factors that promote expression of genes related to lipogenesis and fatty acid synthesis (39). SREBP1c is one member of this family that may 
A

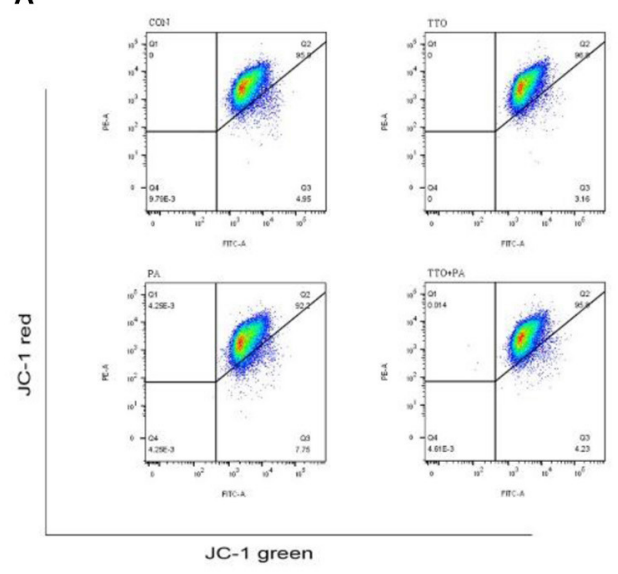

B

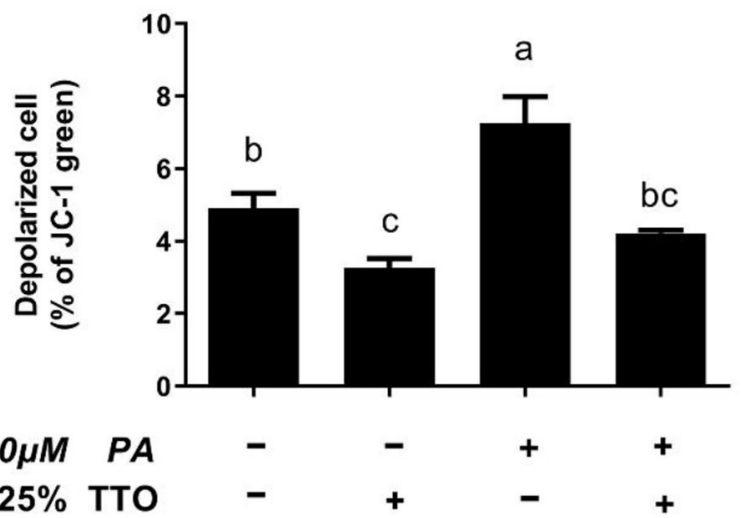

FIGURE 7 | The effect of TTO on mitochondrial membrane potential. (A) Mitochondrial membrane potential in bovine hepatocytes treated with TTO (0.00625\%) and/or PA $(100 \mu \mathrm{M})$. Mitochondrial membrane potential following the different treatments was measured by staining with JC-1. The fluorescence was detected using flow cytometry. The number of depolarized cells is indicated as a percentage of the total cells. (B) The mitochondrial membrane potential percentages in cultures exposed to TTO or PA. All results are expressed as the mean \pm SEM. The letters above the error bars indicate that the difference between groups was significant $(P<$ 0.05). These data are representative of three independent experiments.

modulate many genes related to lipid synthesis and deposition (40), including ACC1 and FAS, which are necessary for fatty acid synthesis in the liver, white fat, and other tissues (41). The incidence of fatty liver increases when expression of SREBP1c and its target genes, FAS and ACC1, is significantly increased in bovine hepatocytes (42). In addition, PPAR $\alpha$ plays a vital role in regulation of mitochondrial and fatty acid oxidation in ruminants, including regulation of downstream targets such as CPT1A and CPT2 (43). In this study, we demonstrated that hepatic synthesis and oxidation of lipids increased in bovine hepatocytes stimulated by PA, which is consistent with a previous study (37). Fragrant herbal essential oils reduce TG content by inhibiting expression of SREBP1c and its target genes involved in fatty acid synthesis (18). As expected, we found that the gene and protein of SREBP1c were remarkably reduced in the $\mathrm{PT}$ group. Interestingly, expression indexes of the downstream genes, including FAS and $A A C 1$, were consistent with a change in SREBP1c expression. However, gene expression of PPAR $\alpha$ and its downstream protein targets, CPT1A and CPT2, increased. Taken together, these results suggest that addition of TTO promotes lipid oxidation and inhibits lipid synthesis by regulating expression of key enzymes in bovine hepatocytes stimulated by PA.

Accumulation of TGs is strongly associated with inflammation, ER stress, and oxidative stress $(1,12)$. Our results show that accumulation of TG over time can activate the NF- $\mathrm{B}$ pathway and aggravate inflammation, which is consistent with a previous study (44). It has been demonstrated that TTO exhibits anti-inflammatory and anti-oxidative activity properties $(16,23)$. NF- $\kappa$ B plays a vital role in intracellular regulation of inflammation and the immune response $(45,46)$.

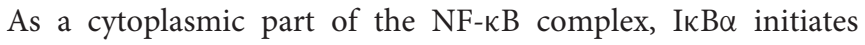
NF- $\kappa B$ activity primarily by inhibiting nuclear localization of the NF- $\mathrm{B}$ complex and inducing phosphorylation of NF-кB p65
(47). NF-кB is a widespread transcription factor implicated in the activation of many genes, including those involved in alcoholic liver injury (48). In our previous study, TTO inhibited NF- $\mathrm{B}$ in goat rumen epithelial cell (49). Our immunoblotting results show

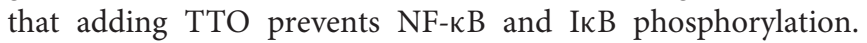
$\mathrm{NF}-\kappa \mathrm{B}$ activity is linked with liver inflammation (50). Following activation, NF- $\mathrm{B}$ causes expression of inflammatory cytokines, including TNF- $\alpha$ and IL-6 (48). Our result show that TTO greatly decreased expression of IL-6 and TNF- $\alpha$ genes in PA-stimulated bovine hepatocytes. Activation of NF- $\mathrm{B}$ can directly or indirectly cause cellular damage by inducing oxidative stress, DNA damage, and lipid peroxidation (51), which lead to cell membrane damage, including mitochondrial fission and eventually cell death. Consequently, it is vital to reduce cellular damage caused by oxidative stress. As expected, TTO supplementation reduced ROS generation in PA-treated bovine hepatocytes, thus protecting lipid bilayers. ROS accumulation leads to collapse of the mitochondrial membrane potential, which is vital for mitochondrial function. Reduced mitochondrial membrane potential promotes mitochondrial permeability by opening pores and allowing release of cytochrome $\mathrm{c}$ from mitochondria into the cytosol, which activates the caspase cascade pathway that induces apoptosis (52-54). We observed that treatment with TTO prevented lipid accumulation resulting from decreased ROS production by preserving mitochondrial membrane potential. Our research suggests that treatment of bovine hepatocytes with TTO can prevent NF- $\kappa \mathrm{B}$ activity, suppress pro-inflammatory cytokines and ROS generation, and preserve mitochondrial membrane potential.

Generation of ROS is associated with ER stress. In addition, high levels of fatty acid directly induce ER stress in bovine hepatocytes $(55,56)$, which precipitates hepatic lipogenesis (57-59). Intriguingly, high levels of fatty acids have been shown to increase lipid accumulation in calf hepatocytes (13), 
consistent with our research. Earlier studies focused on a causative role of ER stress in hepatocytes, and here we tested whether TTO could relieve ER stress in bovine hepatocytes. GPR78 and CHOP are markers of ER stress (60), and we observed that exposing bovine hepatocytes to PA significantly increased expression of the GPR78 and CHOP genes. As predicted, treating these PA-stimulated hepatocytes with TTO reduced GPR78 and CHOP expression. When unfolded proteins accumulate in the ER rumen, chaperone proteins detach from the ER membrane and bind to them. In addition, delayed separation of chaperone proteins can activate the ER membrane protein GRP78. Reaction with unfolded proteins is initiated by aggregation and activation of transmembrane proteins, leading to activation of three classical transmembrane proteins (PERK, IRE1, and ATF6) (61). The PERK-EIF-2A-ATF4, ATF6, and IRE1-XBP pathways all activate the downstream CHOP gene. In addition, HSP70, a molecular chaperone, can induce a response to cellular stressors (62). The present study revealed that expression of EIF-2A (downstream of PERK), ATF4 (downstream of EIF-2A), ASK1 (downstream of IRE1), ATF6, $C H O P$, and HSP70 was triggered at the mRNA level by PA treatment of hepatocytes, and that TTO treatment reversed this effect.

In conclusion, our results show that TTO exerts antiinflammatory effects and acts to promote lipid homeostasis in bovine hepatocytes. These effects are associated with inhibition of NF-кB signaling and SREBP1c expression. Taken together, the results of this study suggest that TTO may be a promising supplement for treatment of imbalanced lipid homeostasis, inflammation and ER stress in dairy cows during the transition period.

\section{REFERENCES}

1. Song Y, Li N, Gu J, Fu S, Peng Z, Zhao C, et al. beta-Hydroxybutyrate induces bovine hepatocyte apoptosis via an ROS-p38 signaling pathway. J Dairy Sci. (2016) 99:9184-98. doi: 10.3168/jds.2016-11219

2. Weber C, Hametner C, Tuchscherer A, Losand B, Kanitz E, Otten W, et al. Hepatic gene expression involved in glucose and lipid metabolism in transition cows: effects of fat mobilization during early lactation in relation to milk performance and metabolic changes. J Dairy Sci. (2013) 96:567081. doi: $10.3168 /$ jds.2012-6277

3. Drackley JK, Overton TR, Douglas GN. Adaptations of glucose and long-chain fatty acid metabolism in liver of dairy cows during the periparturient period. J Dairy Sci. (2001) 84:E100-12. doi: 10.3168/jds.S0022-0302(01)70204-4

4. Reynolds CK, Aikman PC, Lupoli B, Humphries DJ, Beever DE. Splanchnic metabolism of dairy cows during the transition from late gestation through early lactation. J Dairy Sci. (2003) 86:1201-17. doi: 10.3168/jds.S0022-0302(03)73704-7

5. Rukkwamsuk T, Geelen MJ, Kruip TA, Wensing T. Interrelation of fatty acid composition in adipose tissue, serum, and liver of dairy cows during the development of fatty liver postpartum. J Dairy Sci. (2000) 83:529. doi: 10.3168/jds.S0022-0302(00)74854-5

6. Sejersen H, Sorensen MT, Larsen T, Bendixen E, Ingvartsen KL. Liver protein expression in dairy cows with high liver triglycerides in early lactation. J Dairy Sci. (2012) 95:2409-21. doi: 10.3168/jds.2011-4604

7. Bobe G, Young JW, Beitz DC. Invited review: pathology, etiology, prevention, and treatment of fatty liver in dairy cows. J Dairy Sci. (2004) 87:310524. doi: $10.3168 /$ jds.S0022-0302(04)73446-3

\section{DATA AVAILABILITY STATEMENT}

The original contributions presented in the study are included in the article/supplementary material, further inquiries can be directed to the corresponding author/s.

\section{ETHICS STATEMENT}

This experiment was performed under protocols approved by the Animal Care and Use Committee of Yangzhou University, Yangzhou, China and Ethic code is DWLL-202011-201. The authors confirm that they have followed EU standards for the protection of animals used for scientific purposes. Written informed consent was obtained from the owners for the participation of their animals in this study.

\section{AUTHOR CONTRIBUTIONS}

TY performed experiment work, analyzed the data, and wrote the manuscript. XM also performed experiment work. MJ revised the manuscript. $\mathrm{KZ}$ and $\mathrm{ZC}$ : writing-reviewing and editing. $\mathrm{KZ}$ and $\mathrm{GZ}$ provide the support of funding. $\mathrm{KZ}$ contributes to the experimental idea. All authors contributed to the article and approved the submitted version.

\section{FUNDING}

This study was supported by the National Natural Science Foundation of China (No. 32002200), the Research Project of Natural Science Foundation of Jiangsu Province (BK20190898), and China Agriculture Research System of MOF and MARA.

8. Gross JJ, Schwarz FJ, Eder K, van Dorland HA, Bruckmaier RM. Liver fat content and lipid metabolism in dairy cows during early lactation and during a mid-lactation feed restriction. J Dairy Sci. (2013) 96:500817. doi: $10.3168 /$ jds.2012-6245

9. Grummer RR. Etiology of lipid-related metabolic disorders in periparturient dairy cows. J Dairy Sci. (1993) 76:388296. doi: $10.3168 /$ jds.S0022-0302(93)77729-2

10. Herdt TH. Fatty liver in dairy cows. Vet Clin North Am Food Anim Pract. (1988) 4:269-87. doi: 10.1016/S0749-0720(15)31048-3

11. Malaguarnera M, Rosa MDi, Nicoletti F, Malaguarnera L. Molecular mechanisms involved in NAFLD progression. J Mol Med. (2009) 87:67995. doi: 10.1007/s00109-009-0464-1

12. Zhu Y, Guan Y, Loor JJ, Sha X, Coleman DN, Zhang C, et al. Fatty acidinduced endoplasmic reticulum stress promoted lipid accumulation in calf hepatocytes, and endoplasmic reticulum stress existed in the liver of severe fatty liver cows. J Dairy Sci. (2019) 102:7359-70. doi: 10.3168/jds.2018-16015

13. Li X, Huang W, Gu J, Du X, Lei L, Yuan X, et al. SREBP-1c overactivates ROS-mediated hepatic NF-kappaB inflammatory pathway in dairy cows with fatty liver. Cell Signal. (2015) 27:2099-109. doi: 10.1016/j.cellsig.2015. 07.011

14. Catrysse L, van Loo G. Inflammation and the metabolic syndrome: the tissue-specific functions of NF-kappaB. Trends Cell Biol. (2017) 27:41729. doi: 10.1016/j.tcb.2017.01.006

15. Dong J, Bobe G, Guan Y, Li G, Zuo R, Shu, et al. Mitochondrial membrane protein mitofusin 2 as a potential therapeutic target for treating free fatty acidinduced hepatic inflammation in dairy cows during early lactation. J Dairy Sci. (2020) 103:5561-74. doi: 10.3168/jds.2019-17652 
16. Low WL, Martin C, Hill DJ, Kenward MA. Antimicrobial efficacy of liposomeencapsulated silver ions and tea tree oil against pseudomonas aeruginosa, staphylococcus aureus and Candida albicans. Lett Appl Microbiol. (2013) 57:33-9. doi: 10.1111/lam.12082

17. Sailer R, Berger $T$, Reichling J, Harkenthal M. Pharmaceutical and medicinal aspects of Australian tea tree oil. Phytomedicine. (1998) 5:48995. doi: 10.1016/S0944-7113(98)80048-2

18. Jun HJ, Lee JH, Jia Y, Hoang MH, Byun H, Kim K, et al. Melissa officinalis essential oil reduces plasma triglycerides in human apolipoprotein E2 transgenic mice by inhibiting sterol regulatory element-binding protein-1c-dependent fatty acid synthesis. J Nutr. (2012) 142:432-40. doi: 10.3945/jn.111.152538

19. Zhan K, Yang T, Feng B, Zhu X, Chen Y, Huo Y, et al. The protective roles of tea tree oil extracts in bovine mammary epithelial cells and polymorphonuclear leukocytes. J Anim Sci Biotechnol. (2020) 11:62. doi: 10.1186/s40104-020-00468-9

20. Parker JE, Gaughan EM. Partial hepatic resection for treatment of a single liver abscess in a dairy heifer. Vet Surg. (1988) 17:87-9. doi: 10.1111/j.1532-950X.1988.tb00283.x

21. Liu L, Li X, Li Y, Guan Y, Song Y, Yin L, et al. Effects of nonesterified fatty acids on the synthesis and assembly of very low density lipoprotein in bovine hepatocytes in vitro. J Dairy Sci. (2014) 97:1328-35. doi: 10.3168/jds.2013-6654

22. Cousin SP, SR Hugl, CE Wrede, H Kajio, Myers Jr CJ. Rhodes. Free fatty acid-induced inhibition of glucose and insulin-like growth factor Iinduced deoxyribonucleic acid synthesis in the pancreatic beta-cell line INS-1. Endocrinology. (2001) 142:229-40. doi: 10.1210/endo.142.1.7863

23. Zhu Y, Liu G, Du X, Shi Z, Jin M, Sha X, et al. Expression patterns of hepatic genes involved in lipid metabolism in cows with subclinical or clinical ketosis. J Dairy Sci. (2019) 102:1725-35. doi: 10.3168/jds.2018-14965

24. Fu Y, Jin Y, Shan A, Zhang J, Tang H, Shen J, et al. Polydatin protects bovine mammary epithelial cells against zearalenone-induced apoptosis by inhibiting oxidative responses and endoplasmic reticulum stress. Toxins. (2021) 3:121. doi: 10.3390/toxins13020121

25. Yonekura S, Tsuchiya M, Tokutake Y, Mizusawa M, Nakano M, Miyaji M, et al. The unfolded protein response is involved in both differentiation and apoptosis of bovine mammary epithelial cells. J Dairy Sci. (2018) 101:356878. doi: $10.3168 /$ jds.2017-13718

26. Kuang M, Li L, Li C, Wang G. Protective effects of UFL1 against endoplasmic reticulum stress-induced autophagy in bovine mammary epithelial cells. Cell Stress Chap. (2019) 24:1115-25. doi: 10.1007/s12192-019-01033-8

27. Fu Y, Jin $\mathrm{Y}$, Zhao $\mathrm{Y}$, Shan A, Fang $\mathrm{H}$, Shen J, et al. Zearalenone induces apoptosis in bovine mammary epithelial cells by activating endoplasmic reticulum stress. J Dairy Sci. (2019) 102:1054353. doi: $10.3168 /$ jds.2018-16216

28. Xu T, N Ma, Y Wang, X Shi, G Chang, JJ Loor, et al. Sodium butyrate supplementation alleviates the adaptive response to inflammation and modulates fatty acid metabolism in lipopolysaccharidestimulated bovine hepatocytes. J Agric Food Chem. (2018) 66:6281-90. doi: 10.1021/acs.jafc.8b01439

29. Livak KJ, Schmittgen TD. Analysis of relative gene expression data using realtime quantitative PCR and the 2(-Delta Delta C(T)) Method. Methods. (2001) 25:402-8. doi: 10.1006/meth.2001.1262

30. Zhan K, Yang TY, Chen Y, Jiang MC, Zhao GQ. Propionate enhances the expression of key genes involved in the gluconeogenic pathway in bovine intestinal epithelial cells. J Dairy Sci. (2020) 103:5514-24. doi: 10.3168/jds.2019-17309

31. Wang C, Y Guan, M Lv, R Zhang, Z Guo, X Wei, et al. Manganese increases the sensitivity of the cGAS-STING pathway for double-stranded DNA and is required for the host defense against DNA viruses. Immunity. (2018) 48:675-87 e677. doi: 10.1016/j.immuni.2018.03.017

32. Cossarizza A, Baccarani-Contri M, Kalashnikova G, Franceschi C. A new method for the cytofluorimetric analysis of mitochondrial membrane potential using the J-aggregate forming lipophilic cation 5,5,6,6'tetrachloro-1,1'3,3'-tetraethylbenzimidazolcarbocyanine iodide (JC-1). Biochem Biophys Res Commun. (1993) 197:40-5. doi: 10.1006/bbrc.1993. 2438
33. McCarthy MM, Yasui T, Felippe MJ, Overton TR. Associations between the degree of early lactation inflammation and performance, metabolism, and immune function in dairy cows. J Dairy Sci. (2016) 99:680700. doi: $10.3168 /$ jds.2015-9694

34. Sundrum A. Metabolic disorders in the transition period indicate that the dairy cows' ability to adapt is overstressed. Animals. (2015) 5:9781020. doi: $10.3390 /$ ani5040395

35. Ingvartsen KL, Moyes K. Nutrition, immune function and health of dairy cattle. Animal. (2013) 7(Suppl. 1):112-22. doi: 10.1017/S175173111200170X

36. Akbar H, Grala TM, Vailati RM, Cardoso FC, Verkerk G, McGowan J, et al. Body condition score at calving affects systemic and hepatic transcriptome indicators of inflammation and nutrient metabolism in grazing dairy cows. $J$ Dairy Sci. (2015) 98:1019-32. doi: 10.3168/jds.2014-8584

37. Du XT, Shen H, Wang X, Qin D, Xing Q, Ye Z, et al. Adaptations of hepatic lipid metabolism and mitochondria in dairy cows with mild fatty liver. J Dairy Sci. (2018) 101:9544-58. doi: 10.3168/jds.2018-14546

38. Brand C, Townle, SL, Finlay-Jones JJ, Hart PH. Tea tree oil reduces histamine-induced oedema in murine ears. Inflamm Res. (2002) 51:2839. doi: 10.1007/PL00000305

39. Shimano H. Sterol regulatory element-binding protein family as global regulators of lipid synthetic genes in energy metabolism. Vitam Horm. (2002) 65:167-94. doi: 10.1016/S0083-6729(02)65064-2

40. Horton JD, Shah NA, Warrington JA, Anderson NN, Park SW, Brown MS, et al. Combined analysis of oligonucleotide microarray data from transgenic and knockout mice identifies direct SREBP target genes. Proc Natl Acad Sci USA. (2003) 100:12027-32. doi: 10.1073/pnas.1534923100

41. Lecomte V, Meugnier E, Euthine V, Durand C, Freyssenet D, Nemo G, et al. A new role for sterol regulatory element binding protein 1 transcription factors in the regulation of muscle mass and muscle cell differentiation. Mol Cell Biol. (2010) 30:1182-98. doi: 10.1128/MCB.00690-09

42. Li X, Li Y, Yang W, Xiao C, Fu S, Deng Q, et al. SREBP-1c overexpression induces triglycerides accumulation through increasing lipid synthesis and decreasing lipid oxidation and VLDL assembly in bovine hepatocytes. J Steroid Biochem Mol Biol. (2014) 143:174-82. doi: 10.1016/j.jsbmb.2014.02.009

43. Deng Q, Liu G, Liu L, Zhang Y, Yin L, Shi X, et al. BHBA influences bovine hepatic lipid metabolism via AMPK signaling pathway. J Cell Biochem. (2015) 116:1070-9. doi: 10.1002/jcb.25062

44. Angulo P. Nonalcoholic fatty liver disease. N Engl J Med. (2002) 346:1221-31. doi: $10.1001 /$ jama.2015.5370

45. Lin TH, Tamaki Y, Pajarinen J, Waters HA, Woo DK, et al. Chronic inflammation in biomaterial-induced periprosthetic osteolysis: NF-kappaB as a therapeutic target. Acta Biomater. (2014) 10:1-10. doi: 10.1016/j.actbio.2013.09.034

46. Zhang M, Xiao ZZ, Sun L. Overexpression of NF-kappaB inhibitor alpha in cynoglossus semilaevis impairs pathogen-induced immune response. Dev Comp Immunol. (2012) 36:253-7. doi: 10.1016/j.dci.2011.08.001

47. Quivy VC, Lint V. Regulation at multiple levels of NF-kappaB-mediated transactivation by protein acetylation. Biochem Pharmacol. (2004) 68:12219. doi: 10.1016/j.bcp.2004.05.039

48. Barnes PJ, Karin M. Nuclear factor-kappaB: a pivotal transcription factor in chronic inflammatory diseases. N Engl J Med. (1997) 336:106671. doi: 10.1056/NEJM199704103361506

49. Hu ZX, Lin M, Ma XY, Zhao GQ, Zhan K. Effect of tea tree oil on the expression of genes involved in the innate immune system in goat rumen epithelial cells. Animals. (2021) 11:2460. doi: 10.3390/ani11082460

50. Nanji AA, Jokelainen K, Rahemtulla A, Miao L, Fogt F, Matsumoto H, et al. Activation of nuclear factor kappa B and cytokine imbalance in experimental alcoholic liver disease in the rat. Hepatology. (1999) 30:93443. doi: 10.1002/hep. 510300402

51. Blaser H, Dostert C, Mak TW, Brenner D. TNF and ROS crosstalk in inflammation. Trends Cell Biol. (2016) 26:24961. doi: $10.1016 /$ j.tcb.2015.12.002

52. Cetindere T, Nambiar S, Santourlidis S, Essmann F, Hassan M. Induction of indoleamine 2, 3-dioxygenase by death receptor activation contributes to apoptosis of melanoma cells via mitochondrial damage-dependent ROS accumulation. Cell Signal. (2010) 22:197-211. doi: 10.1016/j.cellsig.2009.09.013 
53. Miura T, Chiba M, Kasai K, Nozaka H, Nakamura T, Shoji T, et al. Apple procyanidins induce tumor cell apoptosis through mitochondrial pathway activation of caspase-3. Carcinogenesis. (2008) 29:585-93. doi: 10.1093/carcin/bgm198

54. Wang H, Chen Y, Zhai N, Chen X, Gan F, Li H, et al. Ochratoxin Ainduced apoptosis of IPEC-J2 cells through ROS-mediated mitochondrial permeability transition pore opening pathway. J Agric Food Chem. (2017) 65:10630-37. doi: 10.1021/acs.jafc.7b04434

55. Gentile CL, Frye MA, Pagliassotti MJ. Fatty acids and the endoplasmic reticulum in nonalcoholic fatty liver disease. Biofactors. (2011) 37:816. doi: 10.1002/biof.135

56. Pagliassotti MJ, Wei Y, Wang D. Insulin protects liver cells from saturated fatty acid-induced apoptosis via inhibition of c-Jun NH2 terminal kinase activity. Endocrinology. (2007) 148:3338-45. doi: 10.1210/en.2006-1710

57. Baiceanu A, Mesdom P, Lagouge M, Foufelle F. Endoplasmic reticulum proteostasis in hepatic steatosis. Nat Rev Endocrinol. (2016) 12:71022. doi: 10.1038/nrendo.2016.124

58. Kammoun HL, Chabanon H, Hainault I, Luquet S, Magnan C, Koike T, et al. GRP78 expression inhibits insulin and ER stress-induced SREBP1c activation and reduces hepatic steatosis in mice. J Clin Invest. (2009) 119:1201-15. doi: 10.1172/JCI37007

59. Pagliassotti MJ. Endoplasmic reticulum stress in nonalcoholic fatty liver disease. Annu Rev Nutr. (2012) 32:1733. doi: 10.1146/annurev-nutr-071811-150644

60. Li J, Ni M, Lee B, Barron E, Hinton DR, Lee AS. The unfolded protein response regulator $\mathrm{GRP} 78 / \mathrm{BiP}$ is required for endoplasmic reticulum integrity and stress-induced autophagy in mammalian cells. Cell Death Differ. (2008) 15:1460-71. doi: 10.1038/cdd 2008.81

61. Ron D, Walter P. Signal integration in the endoplasmic reticulum unfolded protein response. Nat Rev Mol Cell Biol. (2007) 8:519-29. doi: 10.1038/nrm2199

62. Seo JH, Park JH, Lee EJ, Vo TT, Choi H, Kim JY, et al. ARD1-mediated Hsp70 acetylation balances stress-induced protein refolding and degradation. Nat Commun. (2016) 7:12882. doi: 10.1038/ncomms12882

Conflict of Interest: The authors declare that the research was conducted in the absence of any commercial or financial relationships that could be construed as a potential conflict of interest.

Publisher's Note: All claims expressed in this article are solely those of the authors and do not necessarily represent those of their affiliated organizations, or those of the publisher, the editors and the reviewers. Any product that may be evaluated in this article, or claim that may be made by its manufacturer, is not guaranteed or endorsed by the publisher.

Copyright (c) 2022 Yang, Ma, Jiang, Cheng, Datsomor, Zhao and Zhan. This is an open-access article distributed under the terms of the Creative Commons Attribution License (CC BY). The use, distribution or reproduction in other forums is permitted, provided the original author(s) and the copyright owner(s) are credited and that the original publication in this journal is cited, in accordance with accepted academic practice. No use, distribution or reproduction is permitted which does not comply with these terms. 